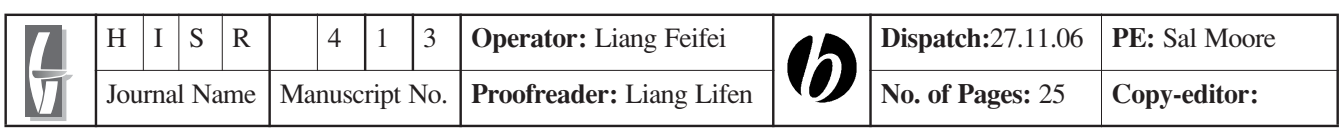

\title{
Nature, production and regulation in eighteenth-century Britain and France: the case of the leather industry
}

\author{
Giorgio Riello \\ London School of Economics
}

\begin{abstract}
Leather was, in the pre-industrial economy, a scarce material used in the production of a wide range of goods. The supply of leather was influenced by the national cattle asset and its slaughtering rate. The difficulty in increasing leather production to meet the demands of a 'consumer revolution' was the subject of theoretical debates and practical intervention. The state controlled and organized the leather market through fiscal and commercial policies. This article offers a comparative analysis of the French and the British leather markets in the eighteenth century. In France, the state assumed an organizational function in the creation of a national leather market. In Britain, by contrast, the state simply regulated an existing market. These different political interventions influenced the dynamics of development of leather production and the leather trades in the two countries. While France suffered from an endemic absence of leather, Britain was able to satisfy its increasing demand efficiently.
\end{abstract}

Leather was, in most pre-industrial economies, a material with many and varied uses. In a world where nature provided all raw materials, leather exemplified the complexity of the boundaries of what has been defined as an 'organic economy'. Leather was the output of the animal world and the input for a wide range of manufactures. ${ }^{2}$ Boyer, in his Political State of Great Britain (I7IO-II), observed that:

If we look abroad on the instrument of husbandry, on the instruments used in most mechanic trades, on the structure of a multitude of engines and machines; or if we contemplate at home the necessary part of our clothing - breaches,

E. A. Wrigley, Continuity, Chance and Change: the Character of the Industrial Revolution in England (Cambridge, I988), pp. I7-32; and E. A. Wrigley, 'The divergence of England: the growth of the English economy in the I7th and I8th centuries', Trans. Royal Hist. Soc., 6th ser., $x$ (2000), II 7-4I, at p. I2I. For a critique of the difficult relationship between economic and business history and environmental history, see C. Meisner Rosen and C. C. Sellers, 'The nature of the firm: towards an ecocultural history of business', Business Hist. Rev., lxxiii (I999), $577-600$

2 L. A. Clarkson, 'The manufacture of leather', in The Agrarian History of England and Wales, vi: $1750-1850$, ed. G. E. Mingay (Cambridge, I989), pp. 466-83, at pp. 468-9. 
shoes, boots, gloves - or the furniture of our houses, the books on our shelves, the harness of our horses, and even the substance of our carriages; what do we see but instances of human industry exerted upon leather? What an aptitude has this single material in a variety of circumstances for the relief of our necessities, and supplying conveniences in every state and stage of life? Without it, or even without it in plenty we have it, to what difficulties should [we] be exposed? ${ }^{3}$

In France the prominent Parisian tanner Rubigny De Berteval similarly reported half a century later that 'les tanneries doivent être regardées en effet, comme objet de première nécessité. Elles tiennent aux besoins de la vie, aux vêtement des gens de campagne, (et) aux chaussures des tous les citoyens'. 4

It is not surprising to find that, in eighteenth-century Europe, the leather industry was considered more important than the metal craft. ${ }^{5}$ Saddlery, coaches, gloves, belts, bookbinding, upholstery, machine belts and footwear used considerable quantities of leather. ${ }^{6}$ Macpherson, in his Annals of Commerce (I783), estimated that the English leather industry was worth a staggering f, IO.5 million and was therefore second in value only to wool. ${ }^{7}$ Leslie Clarkson has contributed to a deeper understanding of the pre-industrial English leather industry. ${ }^{8}$ His research has shown how, in the seventeenth and eighteenth centuries, the leather industry did not grow at the same pace as the rest of the British economy. ${ }^{9}$ F. M. Eden in his Treatise on Insurance ( 1803 ) estimated that the total consumption of leather goods in Britain was f, I2 million. ${ }^{10}$ This was still a high figure, but not as significant as cotton or wool. The relative decline of the leather trades can only be understood by referring to the wider mechanisms governing the pre-industrial European economy and the role of political economy in shaping the idea of national markets. This article aims to examine such issues by comparing the experience of Britain and France. The relative size of the cattle stock and the different functions played by

${ }^{3}$ Political State of Great Britain, ii, ed. A. Boyer (I7Io-II), p. I76.

${ }^{4}$ J. A. Rubigny de Berteval, Observations Importantes Présentées à la Convention Nationales (Paris?, 1793), p. 23.

${ }^{5}$ A. P. Usher, An Introduction to the Industrial History of England (I92 I), p. 254.

${ }^{6}$ G. Riello, 'The boot and shoe trades in London and Paris in the long I8th century' (unpublished University of London Ph.D. thesis, 2002), pp. I-34.

D. Macpherson, Annals of Commerce, Manufactures, Fisheries and Navigation (4 vols., I805), iv. I5.

${ }^{8}$ L. A. Clarkson, 'The organization of the English leather industry in the late I6th and I7th centuries', Econ. Hist. Rev., new ser., xiii (1960), 245-56; L. A. Clarkson, 'English economic policy in the I6th and I7th centuries: the case of the leather industry', Bull. Inst. Hist. Research, xxxviii (1965), I49-62; L. A. Clarkson, 'The leather crafts in Tudor and Stuart England', Agricultural Hist. Rev., xiv (I966), 25-39; Clarkson, 'Manufacture of leather'.

${ }^{9}$ L. A. Clarkson, 'The English leather industry in the I6th and I7th centuries (I563 to I700)' (unpublished University of Nottingham Ph.D. thesis, I960); L. A. Clarkson, 'The English bark trade, I660-I830', Agricultural Hist. Rev., xxii (1974), I36-52, at pp. I38-9. See also A. H. John, 'Agricultural productivity and economic growth in England, I650-1760', in Agriculture and Economic Growth in England, 1650-1815, ed. E. L. Jones (1967), pp. I72-89.

${ }^{10}$ F. M. Eden, Treatise on Insurance ( 1803 ), p. 76. 
London and Paris have to be viewed alongside the role of the state when understanding the structure of the leather market and the balancing of the various leather trades. The concern over the total amount of leather produced was paralleled by fiscal interests and a complex equilibrium of different players within the market.

The production of leather in all pre-industrial economies was confined to the natural world and to a stable cattle asset. In the case of England and Wales the total number of hides and skins produced increased at a low one per cent a year during most of the eighteenth century (Figure I). The stability of leather production has to be seen in conjunction with the dynamics of leather manufacturing and the structure of the meat market. The chain of production, starting with the meat market and finishing with the final product, was particularly complex (Figure 2). As in the case of other raw materials, leather provided the input for a wide range of productive activities, but it differed from them in its peculiar economic nature. Skins and hides can be defined as 'residual' products. The meat market, organized by butchers, provided a main product (meat), two residual products (fat and bones - mainly used in the production of soap, cosmetics and creams) and skins and hides (to be transformed into leather). In the case of cattle, the meat market accounted for ninety per cent of the total value of a slaughtered animal. ${ }^{11}$ Cattle were not, therefore, slaughtered to produce leather, but to supply meat. Leather prices were influenced by the number of cattle, the turnover and the total amount of meat consumed.

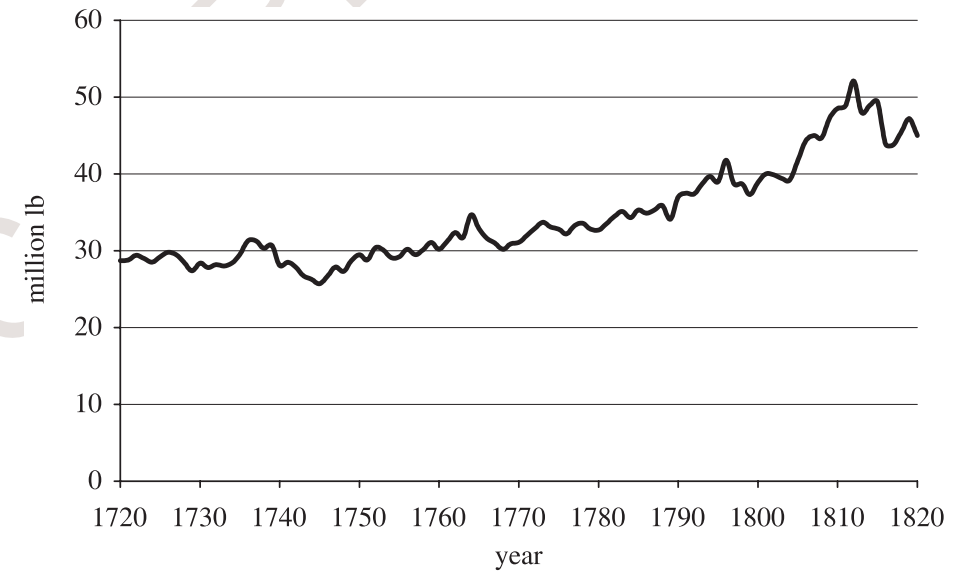

Figure 1. Hides and skins charged with duty in England and Wales, 1720-1820. Source: B. R. Mitchell, British Historical Statistics (Cambridge, 1988), p. 707.

11 Clarkson, 'Leather craft in Tudor and Stuart England', p. 26. 
4 The leather industry in eighteenth-century Britain and France

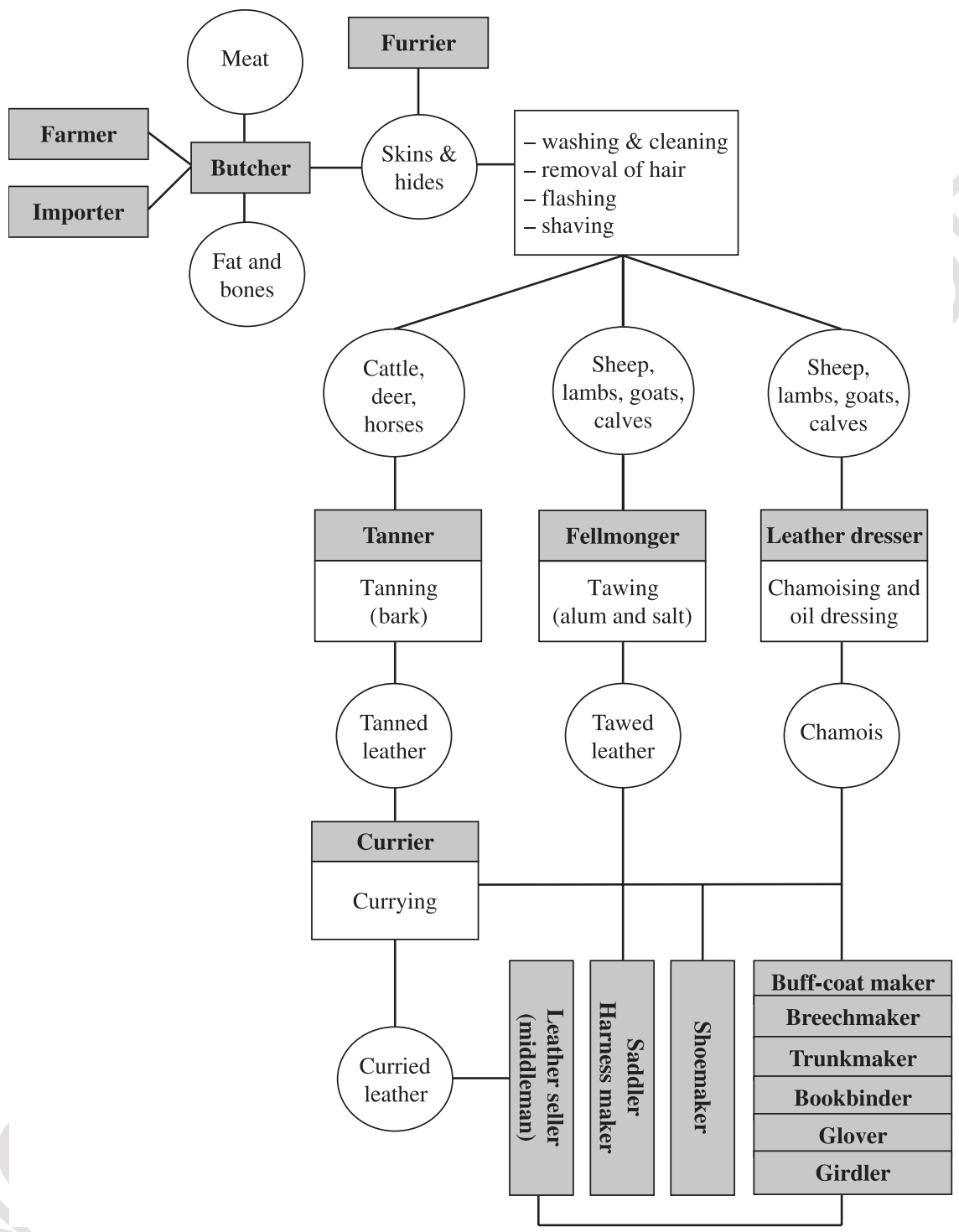

Figure 2. The production of leather and the leather trades in the eighteenth century.

Hides and skins, as residual products, were washed and treated to remove hair. Once refined, they could be subject to any of three different processes that transformed them into leather. Sheep, lamb, calf and goat skins and hides could be treated either through an oil dressing or through tawing. Oil dressing, performed by leather-dressers, was a process that produced chamois, a material characterized by softness and lightness. Tawing, carried 
out by fell-mongers, was a process based on the use of alum and salt, that produced a stronger leather, mainly used for shoe uppers and internal linings. Cattle, deer and horse hides were normally tanned. Tanning, performed by tanners, was a process based on the immersion of hides for protracted periods in bark solutions. Tanned leather could be refined subsequently by currying it. This process, undertaken by curriers, provided the bulk of leather, normally used by shoemakers and saddlemakers. $^{12}$

Although tanners, curriers and leather-dressers were not a cohesive body, they shared similar positions in the productive chain. It was at this level of production that the state was willing to intervene, through taxation and the regulation of a so-called 'intermediate market'. Tanners, curriers and oil-dressers were highly organized groups and were thus able to confront political authorities on a wide series of economic issues. There was also a certain degree of reluctance on the part of the state to control the meat market directly. Widespread breeding and slaughtering - as opposed to the concentration of leather-producing activities - made regulations difficult to implement. By contrast, in early nineteenthcentury England and Wales not more than 3,500 producers were tanning, currying and oil dressing hides and skins. ${ }^{13}$ All of these were easily controlled by the board of excise, which granted annual licences to carry out leather-producing trades. ${ }^{14}$

The relatively small number of the leather-producing businesses was in contrast not only with the structure of the cattle market, but also with the hundreds of thousands of producers in the so-called leather trades. Shoemaking, but partially also saddle-making, belt-making, coach- and harness-making, as well as intermediary activities such as leather-selling, were all small-scale activities on both sides of the Channel. ${ }^{15}$ As quantitative evidence given to the I8I3 select committee on leather shows, tanners, on average, had a capital of $f 4,500$ and a stock of $f$, , ooo. Most of the capital lay in infrastructures and in credit to customers. Similarly, although on a smaller scale, curriers had on average a capital of

12 J. Statham, 'The location and development of London's leather manufacturing industry since the early I9th century' (unpublished University of London M.A. thesis, I965), p. 46.

13 I,700 of them were tanners ( $48 \%$ of the total), I,650 were curriers $(47 \%$ of the total) and I 50 were oil-dressers ( $5 \%$ of the total) (Three Reports from the Select Committee of the State of the Laws Relating to the Leather Trade (Parl. Papers, I8 I6 (386), vi), p. 42).

${ }^{14}$ T. Martin, The Circle of the Mechanical Arts (I8I3), p. 257. They were obliged to specify every room in which leather was deposited, as well as vats and tubs in which it was soaked. The premises were liable to inspection by the excise officers and if the skin did not have the duty mark stamped by the tanner it was seized.

15 Barnett, in his analysis of capital insured by the London trades in the I770s, shows how, while $53 \%$ of London shoemakers insured a capital inferior to $\mathcal{E}_{\mathrm{I}} \mathrm{OOO}$, only I $8 \%$ of tanners and dressers insured a similar capital. At the opposite end of the scale, nearly $20 \%$ of all tanners and curriers insured a capital of more than E, I,Ooo, compared to $3.6 \%$ for the shoemakers (D. Barnett, London, Hub of the Industrial Revolution: a Revisionary History, 1775-1825 (I998), pp. 67, I63). 
$£ 2,000$, ten per cent of which was in stock. ${ }^{16}$ In between the leatherproducing and leather-manufacturing trades (normally defined as leather trades), I5,000 leather-sellers and leather merchants had on average a

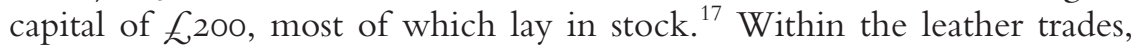
33,000 shoemakers had an average capital of as little as £,50 (Table I). ${ }^{18}$

The different sizes of businesses and levels of capitalization were not the only variations between the leather-producing and the leathermanufacturing trades. Leather itself was the subject of major contrasts between those trades engaged in its production and those engaged instead in its transformation. The practices of tanners and curriers were closely scrutinized by shoemakers and other leather tradesmen, as it was clear that the quality and price of their main raw material depended entirely on the productive processes carried out by the former. Leather was also the subject of continuous debate within the leather trades. Shoemakers, for instance, appealed to parliament on several occasions asking for protection of their trade on the grounds that they used leather to satisfy the basic needs of hundreds of thousands of people, while coach- or harnessmakers used it in the production of luxury goods. This rhetoric clearly

Table 1 Major leather-producing and leather trades in England in 1811

\begin{tabular}{lccccc}
\hline & $\begin{array}{c}\text { Number of } \\
\text { producers }\end{array}$ & $\begin{array}{c}\text { Value of } \\
\text { stock }(f)\end{array}$ & $\begin{array}{c}\text { Capital } \\
(f)\end{array}$ & $\begin{array}{c}\text { Total Capital } \\
\text { of the trade }(f)\end{array}$ & $\begin{array}{c}\text { Gross } \\
\text { profit/ } \\
\text { capital (\%) }\end{array}$ \\
\hline Tanners & $\mathrm{I}, 766$ & $\mathrm{I}, 000$ & 4,500 & $7,947,000$ & 7.5 \\
Curriers & $\mathrm{I}, 648$ & 200 & 2,000 & $3,296,000$ & I 5 \\
Leather sellers & $\mathrm{I} 5,000$ & - & 200 & $3,000,000$ & - \\
Shoemakers & 33,000 & - & 50 & I,650,000 & I 20 \\
\hline
\end{tabular}

Source: Select Committee on Petitions Relating to Duty on Leather (Parl. Papers I8 I2-I3 [593], iv), Table 2 .

16 Very different, however, was the profitability of the two trades: while tanning provided a $7.5 \%$ profit, currying could bring profit of $15 \%$.

${ }^{17}$ Leather sellers appeared in the mid I8th century. They were defined by Campbell as dealers in skins and hides, normally tanned. Their function as middlemen between leather producers and shoemakers, was to buy treated skins or hides from the former and sell small pieces to shoemakers who could not afford to buy an entire hide or skin. Not all leather sellers were similar. They were distinguished in two broad categories: on the one hand, there were 'leather merchants' (commonly called leather sellers) who were buying the leather from the manufacturer (currier, tanner, dresser or fell-monger) and were selling it on their own account; on the other, there were the middlemen, or 'leather factors', who were selling leather on behalf of a manufacturer, normally on commission. The difference between a 'leather merchant' and a 'leather factor' was also the scale of the activity: a leather factor was a small dealer (R. Campbell, The Complete Tradesman (I747), p. 2I7; and see also Statham, p. 44).

18 Select Committee on Petitions Relating to Duty on Leather (Parl. Papers I8 I2-I3 [593], iv), pp. $128-34$. 
echoed wider debates over luxury and necessity in eighteenth-century Britain and France. However, it also offers some insights into issues of production and the natural limits that it encountered.

The fiscal and regulatory actions performed by the state were helped not only by the small number of curriers and tanners, but also by the geography of the skin and hide markets. All London leather was exchanged at Leadenhall market in the City of London. Campbell, writing in I747, reported that leather tanning was 'generally performed in the Country', but added that the tanned leather was 'sent up to London, and bought by several Classes of Leather-Dressers at Leadenhall Market'. ${ }^{19}$ The regulation of the market was helped by the fact that it became, in the course of the century, a national market, with London at the centre of commerce and production. ${ }^{20}$ In 1763 there were fifteen tanneries south of the river in Bermondsey and Southwark, increasing to forty-nine in I822 after the expansion of the leather trades during the Napoleonic wars. ${ }^{21}$ In the early nineteenth century the leather-producing trades were concentrated in Bermondsey, The Grange, Tanner Street and Page Walk. ${ }^{22}$ Such concentration south of the Thames was not only related to the presence of an extensive metropolitan shoe market; it was the meat market that influenced the localization of most of the leather processing activities. Bermondsey provided a place where rents were relatively low and space was available for expanding businesses. Moreover, the regulation of the City of London forbade the setting up of leather manufacturing activities within the City walls for reasons of public health. ${ }^{23}$

The natural centralization of the British leather market in London was not paralleled in France, as the French leather industry remained scattered during the entire eighteenth century. Paris was neither an important slaughtering centre nor the main leather manufacturing city in the kingdom. This was considered to be a major problem in not allowing the easy control of leather production and manufacturing. The French state had to face enormous barriers every time it tried to enforce new legislation. The absence of a national market focused on the capital made it difficult to formulate clear policies on an important raw material and to collect the substantial fiscal revenues that leather produced. ${ }^{24}$ The

${ }^{19}$ Campbell, p. 2 I6 (original emphasis).

${ }^{20}$ London maintained its position in leather production as a result of metropolitan meat consumption and the consequent supply of skins and hides (Clarkson, 'Manufacture of leather', p. 467; J. Burnby, 'The leather industry in Enfield and district', Edmond Hundred Historical Association Occasional Papers, li (1998), I9.

${ }^{21}$ Statham, pp. 57-63.

22 The Sun Fire Office Insurance reports that 36 per cent of all London curriers and tanners were located in Bermondsey (Barnett, p. 68).

23 J. H. Clapham, An Economic History of Modern Britain (3 vols., Cambridge, 1926-39), iii. I70. Curriers were less localized: in I822 only a sixth of London curriers were south of the river (Statham, p. 8I).

${ }^{24}$ Annuaire Général du Commerce et de l'Industrie, de la Magistrature et de l'Administration (Paris, I840), p. lxi. 
eighteenth century was thus dominated by a series of fruitless attempts to create a national leather market in France. Paris never became the neuralgic core of the system and at the beginning of the Revolution the capital city counted just fourteen leather-dressers and twenty-eight tanneries. Most of the Parisian leather-producing and leather-manufacturing businesses were carried out on a very small scale and evidence suggests that the three decades preceding the Revolution saw decline rather than growth for the Parisian leather industry. ${ }^{25}$

It was only during the Revolution that Paris unwillingly acquired a key role in the national leather market. The revolutionary government quickly understood that control of the leather market was a necessary condition for ensuring constant supplies of boots and shoes for the growing national army. In I793, for instance, Berteval proposed that provincial producers should be forced to sell in Paris at least two-thirds of their production in green leather. ${ }^{26}$ By the late eighteen-tens Paris had become the major centre of leather commerce and manufacturing in France, accounting for a third of the total export of French leather. ${ }^{27}$ The capital, however, never became an important site for the tanning and currying of leather. The Halle aux Cuirs and the Bureau des Cuirs, the two major leather markets in the French capital, although deprived of their legal jurisdiction, became central in the national system of leather commerce. ${ }^{28}$

Cattle breeding, meat consumption and the size of a national leather market are three variables strictly linked to each other. The lack of leather in the eighteenth century is subject to important national differences. It is no coincidence that the opposition between the prosperous English beef-eater and the ragged French frog-eater is accompanied by a further contrast between the free-born Englishman wearing leather shoes and the enslaved Frenchman wearing wooden clogs (see Figure 3). There is a direct relationship between these two popular Anglo-French caricatures. The absence of leather and the attempts to create a more efficient national market for hides and skins had their origin in the chronic lack of meat across France and in particular in Paris. Meat consumption remained generally low at least until the first quarter of the nineteenth century. This was a subject of concern for the Napoleonic government who, in I806,

B. Gille, Documents sur l'état de l'Industrie et du Commerce de Paris et du Départment de la Seine (1778-1810) (Paris, I963), p. 58. In the I 760 s only five million francs worth of leather was transacted every year in the French capital. About three million francs was exchanged at the Halle aux Cuirs and two million francs at the Bureau de Cuirs (Paris, Archives Nationales de France (hereafter A.N.), $\mathrm{F}^{12}$ I 462 , 'Regie des cuirs', untitled MSS.

${ }^{26}$ Berteval, Observations Importantes, p. 23.

${ }_{27}$ Recherches Statistiques sur la Ville de Paris (Paris, I 823), table 78.

${ }^{28}$ Quelques Mots Encore sur la Halle aux Cuirs (Paris, I84I), p. 2; L'Innovateur, I6 Jan. I 852 , p. 2. Only well into the I9th century did Paris also became a leather producing centre. In I 840 it was reported that 'Paris est le centre naturel de l'industrie du tanneur; son énorme approvisionnement y amène, de toutes les parties de la France, les bœufs de la plus belle espèces, qui fournissent les meilleures peaux' (Annuaire Général du Commerce, p. lxi). 


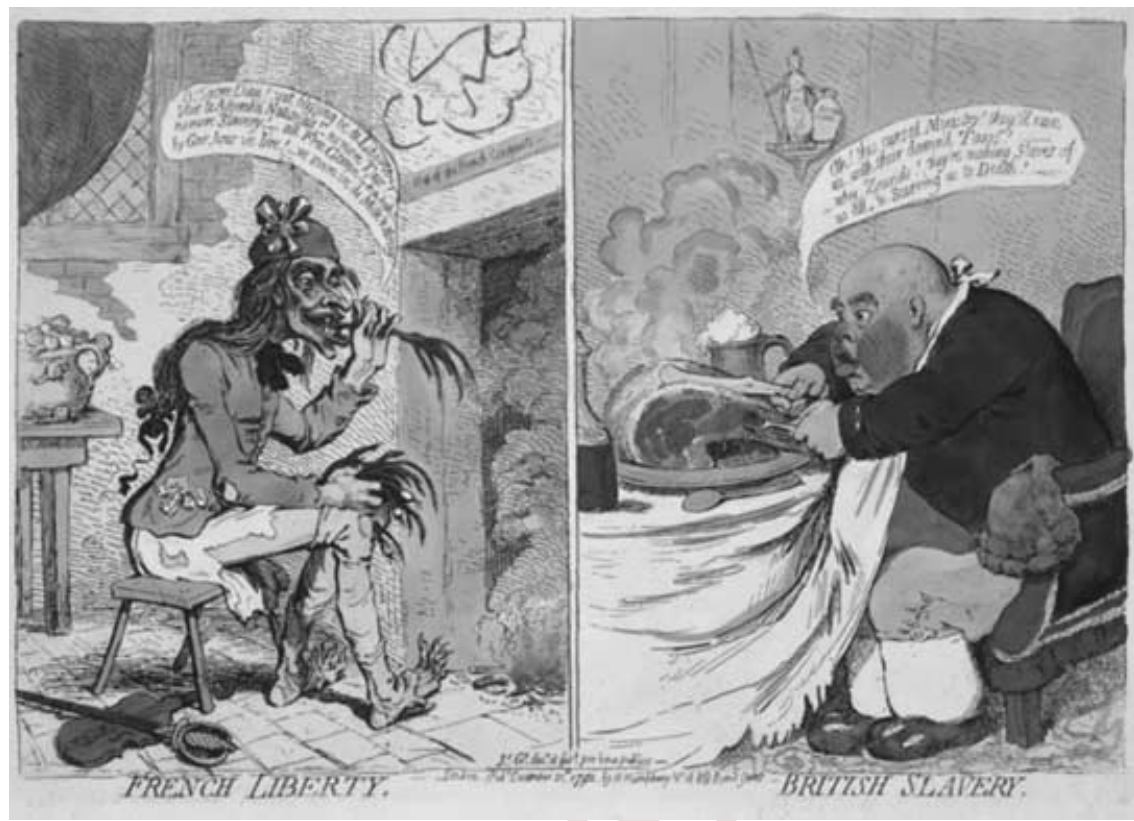

Figure 3. 'French Liberty - British Slavery', caricature by James Gillray (1792). Courtesy of the Library of Congress, Prints and Photographs Division [LC-US ZCA6088].

addressed the problem through a wide-ranging enquiry, one of the many early nineteenth-century recherches nationales. One of the focal points of the enquiry was an attempt to compare France with its overarching enemy across the Channel: England. It produced worrying results: France was disadvantaged not only by its low cattle asset, but also by its high population (Table 2). While England had no more than nine million inhabitants, France had nearly thirty-three million citizens. Even a major investment in cattle was not sufficient to supply the meat and leather markets. ${ }^{29}$

In Britain, where meat consumption was relatively high, intense slaughtering provided a higher amount of leather per capita than in France. However, Britain was facing sustained demographic growth. An increasing population implied that more leather was needed in order to maintain constant per capita consumption. The data available for England and Wales show us that the amount of leather available fell from 5.5 pounds per capita a year in the seventeen-twenties to four pounds per

29 J. B. F. Sauvegrain, Considération sur la Population et la Consommation Générales du Bétail en France (Paris, I 806), pp. 83-I58. Importation was a partial solution to the problem and cattle (in particular young cattle) were imported in the first half of the I9th century, especially from Russia, central Europe, the United States and Hudson Bay (H. de Chavannes de la Giraudière, Récréations Technologiques: Le Coton; les Peaux et Pelleteries; la Chapellerie; la Soie (Tours, I856), p. 74). 
The leather industry in eighteenth-century Britain and France

Table 2 Population and livestock in France and England in 1806

\begin{tabular}{|c|c|c|c|c|}
\hline & \multicolumn{2}{|c|}{ France } & \multicolumn{2}{|c|}{ England } \\
\hline Population & \multicolumn{2}{|c|}{$32,69 \mathrm{I}, 263$} & \multicolumn{2}{|c|}{ 9,000,000 (estimated) } \\
\hline Livestock & no. & $\begin{array}{l}\text { Livestock per } \\
\text { Iooo inhabitant }\end{array}$ & no. & $\begin{array}{l}\text { Livestock per } \\
\text { Iooo inhabitant }\end{array}$ \\
\hline Cows & $3, \mathrm{I} 94,394$ & 98 & I,337,976 & I 44 \\
\hline Cattle & 760,570 & 23 & $\mathrm{I}, \mathrm{OO} 3,482$ & 108 \\
\hline Young cattle & $2,129,576$ & 65 & $2,229,960$ & $24 \mathrm{I}$ \\
\hline Sheep & $30,307,600$ & 927 & $28,989,480$ & 3 I 28 \\
\hline
\end{tabular}

Source: J. B. F. Sauvegrain, Considération sur la Population et la Consommation Générales du Bétail en France (Paris, i 806), p. 82. According to Wrigley and Schofield's estimates, the population of England in I806 was 9,267,570 (E. A. Wrigley and R. S. Schofield, The Population History of England, 1541-1871: a Reconstruction (Cambridge, I98I), p. 534).

capita a century later (Figure 4). ${ }^{30}$ The pressure on leather supply was particularly evident in the fast-growing cities. Eric Hobsbawm has shown how, while the population of London increased 2.5 times in the first half of the nineteenth century, the leather for sale at Smithfield market increased only I.8 times. ${ }^{31}$

Although to substantially differing degrees, both France and Britain were affected by a lack of leather during the so-called long eighteenth century. This was considered a major 'Malthusian' limit for the expansion of the economy of both nations and was accompanied by frequent public initiatives conceived to give some relief to existing constraints. Such measures were complemented by national debates about the most efficient way of achieving these aims and which groups, among the many occupations concerned with leather, should be the main object of regulation. An 'industrial' position put forward ideas concerning the productivity of leather manufacture and the quality of the product. If leather was a scarce commodity, productive methods that saved costs and increased output had to be found. This vision, based on the stability of the raw material asset, contrasted with a 'mercantilist' 32 position that

${ }^{30}$ The analysis of Table 2 and Figure 3 allows us a rough estimate of per capita leather consumption in France of not more than I.5 pounds per year in the early I80os. It is also interesting to observe how short-term fluctuations in per capita amounts of leather available coincided with the major moments of debate in the leather sector, such as the period after I738, the end of the I760 and beginning of the I770s, and I8I2.

31 E. Hobsbawm, 'The British standard of living, I790-I850', Econ. Hist. Rev., 2nd ser., $\mathrm{x}$ (1957), 46-68, at p. 77; B. R. Mitchell, British Historical Statistics (Cambridge, 1988), p. 708.

32 By 'mercantilist', this author refers to the basic principles of early modern mercantilism centred on the role of the state in governing import and export and in securing a positive balance of trade. 


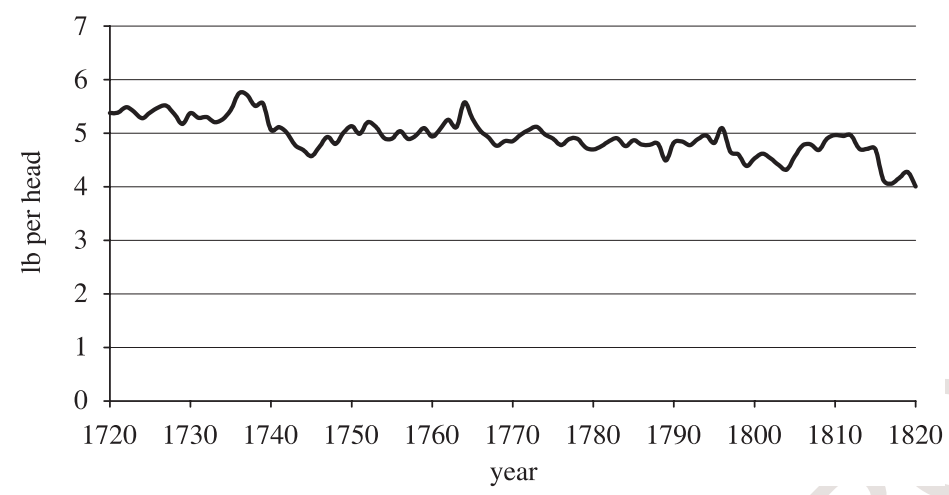

Figure 4. Hides and skins per capita in England and Wales, 1720-1820 (lb per head). Source: Mitchell, British Historical Statistics, p. 707; E. A. Wrigley and R. S. Schofield, The Population History of England, 1541-1871: a Reconstruction (Cambridge, 1981), pp. 458-9.

recognized the need to increase the import of raw leather or cattle, forbid its export and control the export of all leather manufactures. Finally, a third position, fiscal in origin, supported the regulative action of the state on markets through taxation. Fiscal policies had to be aimed not only at raising substantial revenues, but also at creating efficiency in the market, solving problems of misallocation and favouring different leather trades according to need.

The industrial position was surely the weakest option, on both theoretical and practical grounds. The leather trades never showed any substantial degree of innovation, either technological, organizational or productive. ${ }^{33}$ An increase in productivity in the manufacture of leather could be achieved only through technological advance, in particular in the processes of tanning and currying. Tanning was not only a complex productive process, but also required long-term and large-scale investment. The tanning methods used in the early nineteenth century followed practices established three centuries earlier, which had been codified into unchanging rules and regulations. Until i 808 only vegetable bark was allowed for tanning and the Leather Act of I 563 prescribed that strong leather should be tanned for at least twelve months. ${ }^{34}$ The advocates of modernization complained that the use of traditional productive methods prolonged the tanning process by up to fourteen or fifteen months. ${ }^{35}$

${ }^{33}$ On the subject, see R. Thomson, 'The I9th century revolution in the leather industries', in Leather Manufacture through the Ages, ed. S. Thomas, L. A. Clarkson and R. Thomson (I993), pp. 24-33.

34 L. A. Clarkson, 'Development in tanning methods during the post-medieval period (I500-I850)', in Thomas, Clarkson and Thomson, pp. II-22, at pp. I3-I4.

35 W. O. Henderson, Industrial Britain under the Regency: the Diaries of Escher, Bodmer, May and de Gallois, 1814-18 (I968), p. I47. 
Technological and organizational conservatism was not just the result of legislative regulation. In France, as well as in Britain, resistance to innovation by tanners and curriers was considered another major impediment in increasing productivity. Receptivity to change in the sector was particularly slow. Even though a process for rapid tanning was discovered before the French Revolution, it was widely adopted only after $1830 .{ }^{36}$ Spin-offs from one leather trade to another were also minimal. The boot and shoe trade, although using sixty to seventy per cent of all leather, was very tardy in adopting inventions used by other leather trades or leather processing activities. In I 786 John Bull, a glover of Worcester, invented a machine for embossing and crimping leather. This machine, although suitable for use in the manufacture of shoes, was used exclusively in glovemaking. ${ }^{37}$ The process of varnishing leather, allowing a longer life to leather goods, was invented in the seventeeneighties, but was used only in coach-making until the early eighteen-thirties. ${ }^{38}$

Different attitudes towards innovation were also the result of national differences. John Burridge was the inventor of a new process for tanning leather for shoes that allowed a saving of between five and six pounds of leather per hide. ${ }^{39} \mathrm{~A}$ series of memos and letters, now deposited at the Archives Nationales de France, explain how, after some fruitless attempts at finding support in Britain, Burridge decided to patent his invention in France, through the patronage of the French ambassador in London. The main reason for Burridge's choice to patent his invention in France, rather than in Britain, was the dark colour of the leather produced. Burridge stated that the prejudices against the dark colour in England, will require [a] long time to overcome, for the Consumers demand bright light colours, but what do the Colour signify after leather is blacked all over and worn in the dirt? ${ }^{40}$ Burridge's story is symptomatic both of national differences in leather and its uses, and of the competition between Britain and France in the leather market. In France, much more than in Britain, attempts to discover new processes for shortening the time required for tanning multiplied during the first part of the nineteenth century. ${ }^{41}$ In Britain the vitriol tanning process, invented in the seventeenthirties by the Irishman David MacBride and the Englishman John Johnson, was never particularly successful and was replaced in the eighteen-thirties by the chrome tanning process. These chemically-orientated innovations were accompanied by more popular mechanical innovations. In I768 William

${ }^{36}$ Annuaire Général du Commerce, pp. lix-lx.

${ }^{37}$ St. Cripin, 6 Feb. I869, p. 5.

38 St. Cripin, I I Dec. I869, p. I I.

${ }^{39}$ J. Burridge, The Tanners Key to a New System of Tanning Sole Leather (I824).

${ }^{40}$ A.N., $\mathrm{F}^{12} 2283$, 'Letter from John Burridge, Bennet Street, Blackfriars', 28 June I 826.

${ }^{41}$ A.N., $\mathrm{F}^{12} 2286$, untitled MS. Some historians have underlined the I9th-century progress in leather production (see Henderson, p. I48; and W. G. Rimmer, 'Leeds leather industry in the Igth century', Publications of the Thoresby Soc., xlvi (I957), II9-23). 
Powers invented the hand-operated knife to split skins, followed in 1808 by the band-knife machine and in I 828 by the cylinder-knife machine. ${ }^{42}$

'Citoyen Roze', glover and shoemaker in the year XI (I804), reported to a national commission investigating the low supply of leather that 'le peaux de France ne suffisent pas, nous employons dans le cour de l'anné pour une somme considérable de peaux de dain, venant d'Amerique'. ${ }^{43}$ Rose was observing a process of internationalization of the leather market that had been under way for nearly a century. As for many other raw materials, leather was imported into Europe from Brazil and Argentina, the latter being commercially controlled by Britain under the advantageous conditions established by the I7I 3 Treaty of Utrecht. ${ }^{44}$ France relied even more than Britain on the import of hides and leather for the entire eighteenth century. ${ }^{45}$ In the late seventeen-eighties France imported tanned leather worth more than eight million francs from Portugal, Spain, Turkey and the French colonies in Latin America. It also imported more than three million francs of manufactured leather and one million francs in tanned leather from England and the German States (Figure 5). ${ }^{46}$

However, importation could increase only minimally the total amount of leather available. The importing of cattle seemed to provide a good solution, supplying both meat and leather. The best cattle of France and Switzerland found their way to Paris where meat consumption was high, while the north of France was supplied by neighbouring Holland and Belgium. ${ }^{47}$ The result of this strategy was a marked decrease of leather prices in France in the course of the early nineteenth century. ${ }^{48}$

At the manufacturing level, the main measure taken to preserve the national stock of leather was the restriction of its export in the form of raw or manufactured leather. In England, where the situation was not as critical as in France, the export of leather was recognized to be one of the main causes of the material's high price. The economist Joseph Massie thus complained, in the late seventeen-fifties, that:

G. Riello, 'Leather industry and tanning', in The Oxford Encyclopaedia of Economic History, ed. J. Mokyr (Oxford, 2003), pp. 285-6.

A.N., $\mathrm{F}^{12} 2283$, 'Le Citoyen Roze gantier \& bottier, Maison Egalité no. 222' (7 Termidor de l'An XI).

The Art of Tanning and Currying Leather (I774), p. I36.

${ }^{45}$ D. Heimmermann, 'The old regime fiscal system and the decline of the French tanning industry, I759-9I', Proc. Annual Meeting of the Western Soc. for French Hist., xxvi (I999), pp. I $73-83$, at p. I79.

${ }^{46}$ Berteval, Observations Importantes, p. 8. The investigation into the English leather trade for the I786 Eden treaty revealed that 'the English tanned leather for the purpose of Sole leather for its superior quality would be in Demand in France; and that with Coach and Cart Harness, Saddles, Bridles and all sorts of House Furniture besides Boots Legs \&c \&c might cause a greater demand for English leather in France, than that Kingdom would have to return to Great Britain!' (The National Archives of the U.K.: Public Record Office, BT 6/II4 fos. 2I4, 2I5).

${ }^{47}$ Rapport et Projet de Décret Relatifs à l'Interprétation du Décret du 9 Novembre 1810 qui a Fixé de Droit d'Entrée sur les Cuirs Venant de l'Etranger (Paris, I8II), p. 3.

48 Annuaire de la Boucherie (I868), p. 78. 
14 The leather industry in eighteenth-century Britain and France

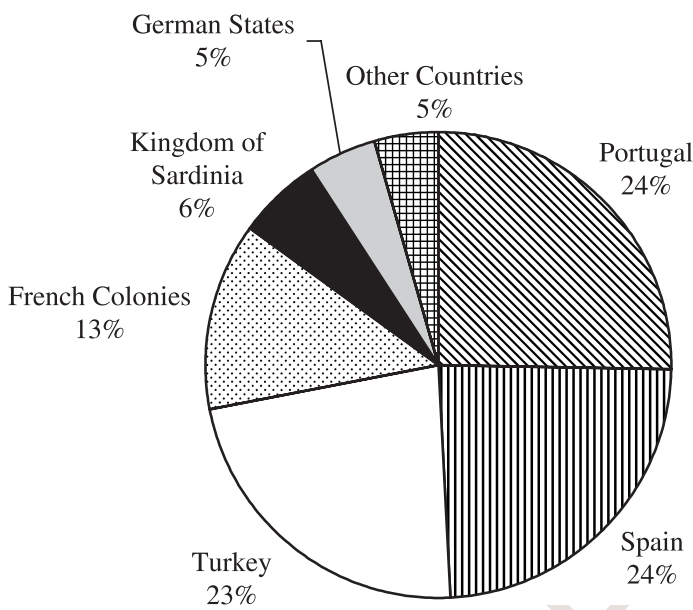

Figure 5. Import of raw leather into France, 1787-89.

Source: H. Depors, Recherches sur l'état de I'Industrie des Cuirs en France pendant le XVIIle Siècle at le début du XIXe Siècle (Paris, 1932), p. 28.

Great Quantities of non-manufactured English Leather have been annually, and for many Years, exported, to all or most of the Countries with which Great Britain carries on any Trade; or, that the Prices of Shoes, Boots and British Leather Manufactures in general, are at this Time, and have been for a Number of Years, much higher they were thirty Years ago. ${ }^{49}$

He calculated that the export of raw leather amounted to a staggering three million pounds Massie, and several other political economists of the second half of the eighteenth century, portrayed this situation as a net loss for the national industry. The lack of leather created a bottleneck for most inland industries and contributed to the deterioration of the British balance of trade. A flourishing consumer industry like shoemaking exported little more than $\mathcal{L}_{\mathrm{IOO}, 000}$ a year of shoes, boots and other footwear. ${ }^{50}$ Tanners, curriers and leather tradesmen complained about the high cost of leather both in Britain and France, and in most cases agreed that the best remedy was a simple prohibition of the export of non-

${ }^{49}$ J. Massie, Considerations on the Leather Trades of Great Britain (I757), p. 3 (original emphasis). Massie suggested that the high cost of leather did not influence the overall consumption of shoes, but its quality. If we consider that labourers' and low-class shoes especially were made of leather during the I8th century, one can understand how this situation would have affected those with lower incomes: 'those valuable People, the Manufacturers and Labourers of the Kingdom, who cannot pay high Prices for Shoes, \&c. must yet pay dearer, or give as much Money for an indifferent Pair of Shoes as would formerly have bought a very good Pair' (Massie, pp. 3-4).

${ }^{50}$ Massie, p. I 8. 
manufactured leather. ${ }^{51}$ The only undesirable effect of the prohibition, or the application of a high duty on the export of leather, was the flourishing of smuggling, especially from Britain to France. ${ }^{52}$

During the eighteenth century demands were repeatedly made in Britain for a return to the statute of I5I 8 which forbade the export of tanned and un-tanned leather. ${ }^{53}$ This statute had been repealed during the reign of Edward $\mathrm{VI},{ }^{54}$ but just a few years later, in $\mathrm{I} 538$, it was again established that the export of leather was a felony severely prosecuted with a penalty of up to one year in prison. ${ }^{55}$ Until the sixteen-eighties the idea that raw leather should not be exported acted to boost the internal production of leather goods. In I680 a new statute allowed the export of raw leather in order to increase the then meagre state revenues. ${ }^{56}$ This new policy led, at the beginning of the eighteenth century, to the establishment of a drawback (an amount of duty remitted or paid back on exported goods) on the export of leather. It is clear, however, that the drawback did not achieve its intention. During the seven-year period from June I 725 to June I 732 the drawback on leather amounted to $£ 73,000$, only $\mathcal{E} 4,000$ of which was derived from manufactured goods. ${ }^{57}$

During the second half of the eighteenth century Britain's position in international leather commerce changed significantly, as it shifted from being a net exporter of non-manufactured leather (tanned leather) to a net exporter of manufactured leather (wrought leather).$^{58}$ The seventeensixties saw a turning point, with the relative need for leather, both for an increasing population and for new manufacturing needs, outstripping the propensity to export it (Figure 6)..$^{59}$

Protests about the drawback on leather exports became acute in that decade. In I 769 curriers, tanners and, above all, shoemakers, in London and other British provincial towns, presented several memorials on the 'present distress of the leather trades' ${ }^{60}$ They complained in particular

${ }^{51}$ Such prohibitions could even extend to the material involved in the tanning or tawing process, such as bark (Arrest $d u$ Conseil d'Estat du Roy, portant Deffenses de Faire Sortir du Royaume des Ecorces d'Arbres servant à faire le Tan pour l'Apprest des Cuir (Paris, I720), p. I).

${ }_{52}$ Observations on the Clandestine Exportation of Leather: with Regard to the Loss arising to the Publick Revenue (I732?), p. I.

5327 Hen. VIII, c.I 4 .

54 I Edw. VI, Stat. ii, iii, c.9.

55 Eliz., Stat.i, c. Io.

5620 Chas. II, Stat. xx, c.5.

${ }^{57}$ Massie, pp. 5-6, I6-I7.

${ }^{58}$ It has to be remembered that most of the leather manufactured exports consisted of shoes (see Riello, 'Boot and shoe trade', pp. I05-8).

${ }_{59}$ While before independence the American colonies were the most important shoe market for Britain, in the later part of the century it was the West Indies that received nearly threequarters of all British leather manufacture exports (J. R. McCulloch, A Dictionary, Practical, Theoretical and Historical of Commerce and Commercial Navigation (2nd edn., I834), pp. 345-6; and see also N. E. Rexford, Women's Shoes in America, 1795-1930 (Kent, O., 2000), pp. II-I3).

${ }^{60}$ T.N.A.: P.R.O., T I/463/33I. See also The Present Situation of the Leather Trade with Respect to the Tanner, Currier, and Complete Manufacturer (I769). 
The leather industry in eighteenth-century Britain and France

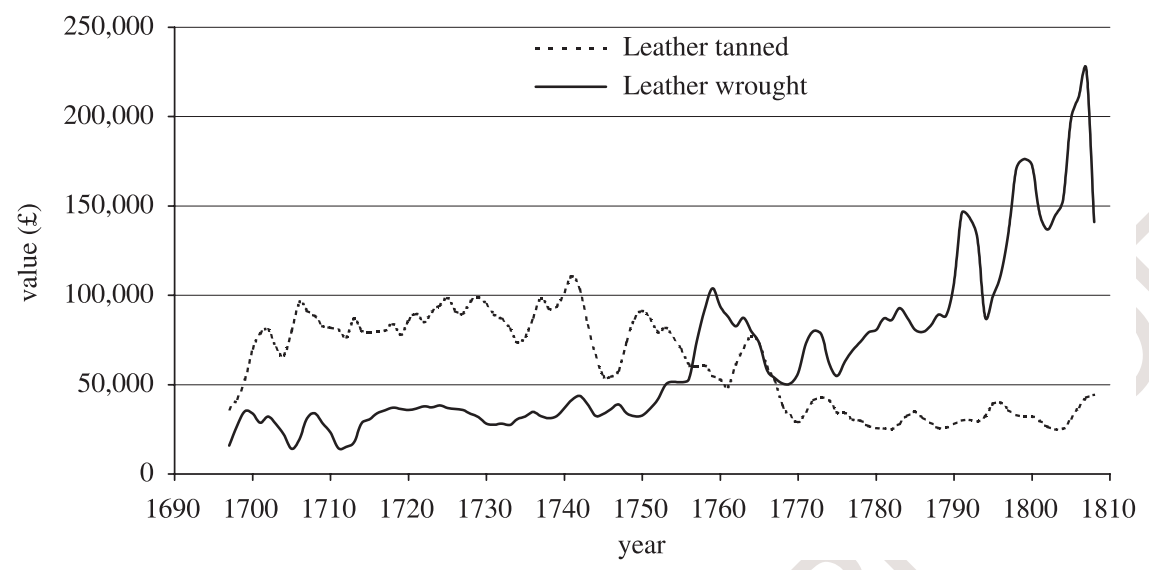

Figure 6. English leather export, 1697-1807 (five year moving average).

Source: E. B. Schumpeter, English Overseas Trade Statistics, 1697-1808 (Oxford, 1960), pp. 31-4.

about the drawback. ${ }^{61}$ Penalizing those who exported raw leather rather than promoting the import of raw hides damaged not only the domestic production of shoes, but leather production as a whole, while "by taking off the Drawbacks on leather \& laying a Duty of one penny a pound on Exported Leather the Government would gain twenty to Thirty thousand pounds per Annum'. ${ }^{62}$ This association between shoemakers, curriers, tanners and leather-sellers in pursuit of a low level of duty on imports and a high duty on exports came to an end at the beginning of the nineteenth century. After I8I2 the Cordwainers' Company, with the support of other leather trades but in opposition to the leather-producing trades, began to ask for an increase of the duty on imports and excise tax on leather in order to finance a more substantial drawback on the export of finished articles. ${ }^{63}$

The eighteenth-century debate on leather regulation, both in France and in Britain, can be reconstructed through the analysis of a long series of petitions, acts and tracts. Their common denominator is a careful discourse constructed around the importance of leather manufacture within the wider economy and the role played by local and national authorities in regulating the leather market. ${ }^{64}$ The context of such a

61 G. Riello, 'The shaping of a family trade: the Cordwainers' Company in I8th-century London', in Guilds, Society and Economy in London, 1450-1800, ed. I. Gadd and P. Wallis (2002), pp. I4I-59, at pp. I42-3.

62 T.N.A.: P.R.O., T I/463/333.

63 C. H. W. Mander, A Descriptive and Historical Account of the Guild of Cordwainers of the City of London (I93 I), p. 89.

${ }^{64}$ See, e.g., D. J. Heimmermann, 'Crisis and protest in the guilds of I 8 th-century France: the example of the Bordeaux leather trade', Proc. Annual Meeting of the Western Soc. for French Hist., xxiii (I996), 43I-4I. 
debate was found in the Smithian concept of the 'Wealth of the Nation'. The provision of such an important raw material depended not only on a single branch of the national economy or on the local equilibrium of supply and demand, but involved the entire economic system.

As already seen with reference to the I 759 legislation on leather, one of the paramount objectives of the French state was to construct a national leather market. In France the leather market was, in the first half of the eighteenth century, regulated through different provincial laws based on a wide range of local taxes and policies. Only Paris fell under the direct regulative action of the central government who controlled the market through the Halle aux Cuirs and the Bureau des Cuirs. This complex system, constructed to satisfy fiscal purposes, presented an underlying organizational vision of the structure of transactions within the market. ${ }^{65}$ The contradictory, anti-economic and sometimes confusing laws on leather applied in the French provinces were considered to be the best method of replying to local dynamics within the provincial leather markets. Problems of quantity, quality and variety of leather could be resolved only through the direct action of an authority that was aware of the particular conditions under which a market was operating. Such a system was, however, criticized by those who supported the intervention of a stronger state, capable of imposing a universal political economy and of rationalizing the system in order to maximize the national wealth. Within this framework the leather market ceased to be constituted by physical entities and became a modern ideal place. This was the background to the extension of the Parisian legislation to the whole kingdom in $1759 .{ }^{66}$ It abolished the old legislation on leather of 1580 and established uniform taxation throughout the country, based on excise and export duties to which was added an anti-industrial duty on manufacturing. ${ }^{67}$

The new national system was soon accused of being too complicated and unsuitable for different regional or local needs. If, on the one hand, it unified the various local mechanisms under a 'droit unique' with only one stamp duty, on the other, the wide variety of leather and the

${ }^{65}$ In I 724 , for example, a sentence of the lieutenant général de police of Paris established that shoemakers' wives were not admitted to buy leather instead of their husbands. Transactions had to take place in the clearest way, avoiding situations of conflict or bribery, common features in provincial markets (Bibliothèque Nationale de France (hereafter B.N.), 8-Z Le Senne4287(II), Sentence de Monsieur le Lieutenant Général de Police, qui fait Défences à Toutes les Femmes en Puissance de Mari d'Aller à la Halle aux Cuirs, pour y Lottir, \& Faire des Déclarations (5 Apr. I724); and B.N., 8-Z Le Senne-4287(I2), Arrêt Contradictoire du Concil d'Estat du Roy (Io Aug. I737)).

${ }_{66}$ A.N., $F^{12}$ I 462 , untitled MS.

${ }^{67}$ Clément and A. Lemoine, M. de Sihouette, Bouret et les derniers Fermiers Généraux (Paris, I872), p. I33; J. A. de Rubigny de Berteval, Mémoire sur les Tanneries du Royaume, Présenté aux États-Généraux (Paris, 1790), p. 3; Édit . . Portant Création de Neuf Cents Mille Livres de Rentes Héréditaires sur les Deniers Provenans du Droit établi sur les Cuirs (Paris, I76I), p. I. 
enormous differences in leather processing made the regulations highly complex. ${ }^{68}$ The purpose of the new system was to control every part of the trade. Legislation, however, had to enter into such a high degree of detail that the smooth functioning of the market was rendered impossible. The weight of control over French leather was considered oppressive. Each hide or skin had to be subject to:

déclaration au changement d'Etat, prise en compte, prise en décharge, certificat de décharge, apposition de marque de préparation ou de change pesage, marque de perception ou de décharge, déclaration de vente, soin de conserver, laissés passer, crédit ou caution pour l'étranger, décharge, visa aux frontières, visite, contre-visite, perquisition, récensement, vérification, acte de leprise pour forme documentaire.

These were part of the 'nombre infini de formalités auxquelles il (cuir) est subjetté'. ${ }^{69}$ Each of these stages was used not only for control, but also for the application of a tax. This was possible thanks to the survival of a large and complex body of legislation predating the 1759 act. $^{70}$ Breteval calculated in 1790 that leather was very heavily taxed through stamp duty and also through duties on imports and exports, on internal transport and on manufacturing processes (Table 3).

The tax represented considerable income for the French state, generating four to five million francs a year for the treasury. ${ }^{71}$ The problem was not, however, simply one of fiscal imposition. Even though the stamp duty (droit de la marque) remained, until I789, at a high fifteen

Table 3 Tax burden on leather in France after 1759

\begin{tabular}{lc}
\hline Type of Duty & $\begin{array}{c}\text { Percentage of the } \\
\text { Total Value }\end{array}$ \\
\hline Stamp Duty & I 5.0 \\
Import Duty & IO.0 \\
Export Duty & 3.5 \\
Transport Duty & I 2.0 \\
Tax on raw material & 2.0 \\
Tax on manufacturing & IO.0 \\
Total & 52.5 \\
\hline
\end{tabular}

Source: J. A. de Rubigny de Berteval, Mémoire sur les Tanneries du Royaume, Présenté aux ÉtatsGénéraux (Paris, I790), p. 33; H. Depors, Recherches sur l'État de l'Industrie des Cuirs en France pendant le XVIIIe Siècle at le début du XIXe Siècle (Paris, 1932), p. 50.

${ }^{68}$ Depors, p. 50; A.N., $\mathrm{F}^{12}$ I464, untitled MS., fo. 2. See also Heimmermann, pp. I73-83.

${ }^{69}$ A.N., $F^{12}$ I 464 , untitled MS., fo. I.

${ }^{70}$ Heimmermann, pp. I76-8.

${ }^{71}$ J. A. de Rubigny de Berteval, Lettre Adressée à Tous les Fabriquants et Commerçans en Cuir du Royaume (Paris?, I790), p. I. 
per cent, the real difficulty was considered to be 'pas ce droit approchant de is p. Ioo de la valeur des cuirs qui nuit à cette branche de commerce, mais la forme de cette perception' ${ }^{72}$ Before the hide was taken out of the pit, the tanner had to call a commission for the marking of the hide itself. After the hide had been treated the first stamp had to be verified and a second made. The double stamp did not imply a fulfilment of the law. Leather was marked during the different stages from hide to finished leather, but the stamp could disappear very easily. Other stamps followed, such as those of the 'contrôlleur-visiteur et marqueur', the 'prud'homme' and the 'vendeursdéchangeurs-lotisseurs'. ${ }^{73}$ The repetition of stamps could damage leather, and this created constant problems between commissions and tanners. ${ }^{74}$

Such detailed legislation was considered one of the main reasons for the decline of tanning and currying in France in the second half of the eighteenth century. In I760, 36,000 hides were tanned in Paris; in I775, total production had fallen to less than $6,000 .{ }^{75}$ Similarly, provincial tanners complained in $\mathrm{I} 775$ that the previous fifteen years had been dominated by a constant decline of leather production in the whole kingdom. ${ }^{76}$ Protests from all provincial centres engaged in leather production called for a radical revision of the duty system. The reply, in I775, was a timid one: the new law was more interested in rationalizing the existing legislation on leather than in reforming the system. ${ }^{77}$ It did not change substantially either the level of taxation or the control exercised by the state. It simply provided a clear framework for more effective governmental intervention. ${ }^{78}$

It was only with the Revolution that the leather legislation was profoundly reformed, not only in keeping with new political and ideological principles, but also to respond to changed national needs. The assemblée nationale established, in March I790, that 'L'exercise du droit de marque des Cuirs sera supprimé dans toute l'étendue du Royaume, à compter du premier Avril prochain'. ${ }^{79}$ The repeal of the stamp duty was

72 Cited in R. Picard, Les Cahiers de 1789 et les Classes Ouvrières (Paris, I9Io), p. 2 Io.

Dupont de Nemours, Rapport sur le Droit de Marque des Cuirs (Paris, I804), p. I9.

A.N., F ${ }^{12}$ I 462, 'Procedés, inventions, I747-88', fos. 5-6.

A.N., F ${ }^{12}$ I 464, 'Extrait du mémoire présenté au Roi et à l'Assemblée des Notables par le Sieur de Rubigny de Berteval, tanneur à Paris', undated document. A few years later they said that 'les Anglais se sont enrichis de notre ruine en fournissant les nations voisines qui jadis s'approvisionnaient en France' (cited in C.-L. Chassin, Les elections et les Cahiers de Paris en 1789 (4 vols., Paris, I888), ii. 482).

76 Paris had 42 tanneries in I759, but only $\mathrm{I} 2$ in I775; Bodeaux passed from 27 to four tanneries; and Chateldou lost all of its 200 tanneries (Berteval, Mémoire, p. 40).

77 Berteval, Lettre, p. 2.

78 L'arrêt du Conseil of 27 May I777, for example, established a very tight rule: 'Enjoint aux tanneurs et aux ouvriers employant-cuirs, d'ouvrir à la première sommation des commis, leurs tanneries, ouvroirs, magasins et autres lieux dépendant de leurs maisons pour y faire les visites nécesssaires, à peine de 300 livres d'amende' (Depors, p. I22).

79 Lettres Patentes... sur le Décret de l'Assemblée Nationale du 22 mars 179o, Concernant la Suppression de l'Exercice du Droit de Marque des Cuirs (Paris, I790), p. I. 
viewed as the suppression of a fiscal burden, and also as an important simplification in leather production. The law was welcomed by tanners, curriers and shoemakers, who considered it the moment at which 'le commerce sur les cuirs de France a reconquis sa liberté'. ${ }^{80}$ Such freedom was, in reality, essential to support the new leather needs of the French nation. ${ }^{81}$ Far from adopting the expected laissez-faire approach, the revolutionary government soon took an active role in revitalizing the leather sector. The army required large quantities of leather for boots, belts, carriages, buckets, and so on, that could be produced only by a larger and more efficient market. The government thus intervened in different ways, for example, from I790, supporting the development of tanning à la flotte, a process much quicker than traditional tanning systems. ${ }^{82}$

The revolutionary government recognized that the preservation of the Halle aux Cuirs was one of the easiest ways to control the Parisian market. It underlined that 'la Halle aux Cuirs, par son importante utilité, mérite la plus grande attention, car elle est d'un usage presque général, par ses raports avec la société'. ${ }^{83}$ This was a relevant point, in particular for shoemakers. The Halle provided the place where small shoemakers could buy pieces of leather or small hides. During the debate about the possible closure of the Halle, questions were raised about alternative methods for buying leather. The cordonnier pouvre lamented that, if the Halle were to be closed, he would be forced to buy from magasins particuliers (especially curriers), paying high prices and consequently increasing the cost for consumers. ${ }^{84}$ Liberalism was short lived. The years of the directorate and the Napoleonic empire saw a return to an old fiscal idea. The I 8 io fiscal law established a duty of five francs per hide or skin with no distinction as to type or quality. Special duties were applied to particular import markets: a piece of leather imported from Buenos Aires had a import duty of thirty-five francs; from Caracas sixteen francs; and horse hides were taxed at six francs a piece. ${ }^{85}$ In I 8 I 4 the duty on leather amounted to 326 million francs, 240 million on ox hides, fifty-six million on cow hides and thirty million on kid. ${ }^{86}$

The historiography of the eighteenth-century political economy has traditionally set the British laissez-faire approach in opposition to the strict

${ }^{80}$ Rubigny de Berteval, Lettre, p. 2. See also Rapport Fait au Nom du Comité des Finances, a l'Assemblé Nationale: le 14 août 179o: sur la Répartition de la Contribution en Replacement des Grandes Gabelles (Paris, I790); Troisieme Rapport Fait au Nom du Comité des Finances: sur le Replacement de la Gabelle et des Droits sur les Cuirs (Paris, I790).

81 Considération sur le Projet de Supprimer les Droits sur les Cuirs (Paris, I790), pp. I-6.

82 Depors, p. I9.

83 B.N., 8-FM-3336, M. Lulier, Adresse à l'Assemblée Nationale, pour les Fabricants, Marchands, et Ouvriers qui Employent les Cuirs (I79I), p. 4.

${ }^{84}$ Lulier, p. 27.

85 Rapport et Projet de Décret, pp. I-4.

86 A.N., F ${ }^{12}$ 2286, 'A Son Excellence Ministre du Roy, I Aôut I8I4'. 
regulative regime of the French state. This is a crude simplification, and it is important to consider not only the statutory aspects of legislation, but also its application. A comparative analysis of the French and British leather markets underlines the diversity of systems for enforcing the law in the two countries. In London the guilds were in charge of administering the law and could punish transgressors within and beyond their companies. The state had granted the guilds powers to protect themselves and the administration, and associated cost, of such powers did not necessarily involve the political or judicial authority. Normally a simple fine was the end of the prosecution. In Paris the authority assumed by the state in the regulation of the leather market restricted the power exercised by curriers, tanners and shoemakers in their trades. The contrôlleurs de cuirs, for instance, although directly dependent upon the tanners, were considered to be civil servants. Legal actions against those not respecting the rules on leather were dealt with directly by the police of the Chatelet. Guilds protested not only because their powers were curtailed, but also because of the resulting ossification of their trade. The state authority could also be arbitrary. A much advertised example was the case of a certain Bienaige, a Parisian shoemaker who refused to accept the visit of the contrôlleurs de cuirs and was sentenced by the police to an enormous 500 livres fine. ${ }^{87}$

By contrast the state in Britain was unwilling to regulate the leather market strictly. Its objective was to raise funds without getting directly involved in a system whose complexity surpassed control. Import, export and excise duties were partially imposed in accordance with treasury needs, but also took into consideration the several actors involved in the production and use of leather. Any problems that arose between them had to be resolved not through general legislation, as was the case in France, but through parliamentary initiatives. Shoemakers, curriers, leather-dressers, leather-sellers, saddlers and so on, had to negotiate potential difficulties among themselves. Where shared concerns arose they were forced to join in petitioning parliament. The state in this case assumed a regulatory rather than an organizational function.

The very real differences between the French and the British leather industries can be misleading, creating the false impression that no problems were present in the British leather market. Shoemakers frequently fought against tanners and other leather producers. The quality of tanning influenced the quality of leather and consequently the price of finished leather goods, ${ }^{8}$ and the so-called leather trades repeatedly tried to impose a series of controls and limits on the activities of tanners, curriers and other leather producers. A second set of issues arose from the

87 BN, F 237I 5-38, Sentence de Police Contre le Nommé Bienaise, Cordonnier, pour Refus de Souffrir la Visite des Contrôlleurs de Cuirs de Paris (Paris, I727).

88 Brief Directions how to Tanne Leather According to a New Invention Made by Severall of the Principal Tanners using Leadenhall Market (I680?). 
relative boundaries of different trades. During the seventeen-thirties, for example, the Cordwainers' Company brought fourteen legal actions against the Curriers for infringing the act of James I by illegally practising the shoemakers' trade. ${ }^{89}$ The quarrel reveals an endemic problem in the raw material market, namely the boundaries between the shoemakers', curriers' or tanners' occupations. Were curriers allowed to cut hides and sell them to shoemakers or journeymen shoemakers? Or was the cutting of hides and skins, already in the form of leather, part of the shoemaker's trade? An act of parliament of I739 established that shoemakers, leathersellers and curriers could deal freely in all kinds of leather at any town or market. ${ }^{90}$ However, it also confirmed that different trades could not undertake similar tasks. This decision particularly affected the shoemaking trade as it changed the rules governing buyers and sellers. ${ }^{91}$ It was only between I8I 3 and I8I6 that a parliamentary select committee discussed abolishing the act, leading, after I830, to the abolition of any legal separation between different leather producing or manufacturing trades. ${ }^{92}$

Contrasts between shoemakers and tanners could also be highlighted by their different interests in fiscal and excise measures. As early as I694 metropolitan tanners sent a petition to parliament to prevent an increase of one penny in the pound on the leather export duty. They supported their request by stating that England had 'great quantities of Russia and Turkey Leather imported (of which there is little notice taken) that is now become a great wear in Shoes and Several other Uses'. ${ }^{93}$ Shoemakers, however, were of a different opinion and thus petitioned parliament supporting an increase of the duty; they were accused by tanners of conspiring to reduce the price of leather and 'make the exporter pay'. ${ }^{94}$

The role played by Leadenhall market becomes clear in the light of what has been discussed above. ${ }^{95}$ Leadenhall was the result of a natural

89 E. Mayer, The Curriers and the City of London: a History of the Worshipful Company of Curriers (I968), pp. I23-34.

90 Riello, 'The shaping of a family trade', pp. I $5 \mathrm{I}-2$.

91 Still in $\mathrm{I} 784$ it was confirmed that 'No Tanner shall exercise the Trade of a Currier, Shoemaker, Butcher, or other artificers using or exercising the cutting or working of leather' (Report from the Committee on Acts Relating to Tanners, Curriers, Shoemakers and Other Artificers (24 Geo III, c. 19) (Parl, Papers I 807 (40), ii), p. 3).

92 Select Committee on Petitions Relating to Duty on Leather; Statham, pp. 8 I-2.

93 Petitions and Addresses to Parliament, Reasons Humbly Offered to the High Court of Parliament Against Laying a Duty of One Peny per Pound upon Tann'd Leather, etc. (I694).

${ }^{94}$ Reasons Humbly Offered. Similarly in I700: Laws and Statutes, Act for Laying a Duty upon Leather for the Term of Three Years and Making Other Provision for Answering the Deficiencies (I797); and $8 \& 9$ Will. III, c.2I; A Clause in the Act for laying a duty on Leather and Skins (I700). Petitions and Addresses to Parliament, To the High Court of Parliament, some Considerations Humbly Proposed before Reviving of the Acts for Transporting of Leather (I700).

95 The primary London leather market was Leadenhall, operative from I4O3 to I833. Smithfield specialized in hides and was active until I880. For sheep skins the most important markets were Blackfriars Road, Southwark Bridge Road and Whitechapel (Statham, p. 83). 
need for a transaction market, rather than the outcome of the state's organizing and shaping the leather sector and all its transactions. As we have observed, there was certainly a fiscal interest in the sale of hides and skins, but the state was unwilling to implement a complex body of legislation concerning the leather system. One case encapsulates the approach that was adopted. Throughout the eighteenth century the lord mayor and the court of aldermen, in association with the mayors, bailiffs and lords of fairs and markets, appointed searchers and sealers of leather annually. In I 807, however, the committee on leather underlined how 'It appears that in most parts of the country these Regulations are obsolete and disregarded; that, except in Bristol and a few other principal markets, Searchers, if at all appointed, are only pro formâ' ${ }^{96}$ In Leadenhall, for example, it was only in I790 that searchers became operative, as a result of the need to control the quality of leather at a time of high demand. ${ }^{97}$

During the Napoleonic wars, leather became increasingly scarce, and it became necessary to impose quality control on such leather as was available. In I 803 an act was passed (the so-called 'Flaying Act') empowering the Cordwainers' Company, together with the Curriers and the Butchers, to control the flaying of hides and skins in the City of London, and to inflict fines in cases where damage had been done when removing the hide or skin from the carcasses of the animals. ${ }^{98}$ The Flaying Act also established that all hides within five miles of the City of London had to be carried to Leathenhall market in order to be sold. Eight inspectors were appointed by the Cordwainers' Curriers' and Butchers' companies. This system of control had a dual function: it allowed the quality of leather to be monitored; and it gave substantial financial aid to the companies. Between October I803 and March I806 more than 69,400 was collected from fines and divided between the three companies, 99 most derived from butchers found guilty of having damaged hides during slaughtering. ${ }^{100}$

Intervention by the British state went beyond straightforward taxation. An attempt to impose a tax on leather failed in I694 on the grounds that such raw material was one of the fundamental inputs of most British industries. Just three years later a tax was imposed as a 'temporary' measure for three years in order to raise money for the expensive wars on the Continent. In I7IO it was reintroduced at one penny on the

96 Report . . . relating to Tanners, Curriers, Shoemakers, p. 6.

97 This article does not examine the complex problems faced by the British leather market during the period I805-I5. On the subject, see Select Committee on Petitions Relating to Duty on Leather, pp. 9-34.

98 W. H. Dutton, The Boots and Shoes of our Ancestors (I898), p. 4.

${ }^{9}$ N. Sutton, 'Metropolitan artisans and the discourse of the trades, I750-I825' (unpublished University of Essex Ph.D. thesis, I994), p. 5I.

100 Mander, p. 90. For a wider analysis of the Flying Act and the control of leather production in Britain, see W. M. Stern, 'Control v. freedom in leather production from the early I7th to the early igth century', Guildhall Miscellany, ii (I968), 438-58. 
pound on all tanned, tawed or dressed hides and skins in Great Britain. ${ }^{101}$ The tax on leather brought the treasury more than f2I, Ooo a year, making its repeal unlikely. ${ }^{102}$ As in France, protests did not necessarily focus on the tax itself, but often on the method of raising it. As soon as the tax was imposed, it provoked a heated debate in the leather trades. ${ }^{103}$ Shoemakers, for example, complained that the tax was on weight and not on value, and therefore bore more heavily on the low-quality leather normally used for shoes. ${ }^{104}$ Modifications in the rate of excise and duties remained at the heart of tensions and confrontation within the leather market throughout the eighteenth century.

The problem of leather taxation re-emerged when a new tax system was introduced in I8I2 (52 George III, c. 94), increasing the duty on leather from one penny to three pence per pound. Early in I8I 3 all counties petitioned parliament against the tax, arguing that an increase in the excise duty had caused an estimated decline of about twenty per cent in the value of leather in Britain. ${ }^{105}$ Curriers, tanners and shoemakers were forced to join together to petition parliament in I8I 3 and again in I 8 I6. ${ }^{106}$ This second attempt to revise the duty and excise systems was more successful than that of I 8 I3. The shoemakers' claim that the military consumption of the previous years had kept leather prices extremely high could hardly be ignored, and the chancellor of the exchequer was forced to appoint a committee for the consideration of the tax on leather. ${ }^{107}$ The committee, however, did not support any reduction of the tax and other petitions followed in I 8 I 8 and I $822 .{ }^{108}$ Only in I 822 was the tax lowered again to one penny per pound, and it was finally repealed in I $830 .^{109}$

101 Raised by a halfpenny in I7I I (Io Anne, c.26). S. Dowell, A History of Taxation and Taxes in England from the Earliest Times to the Year 1885 (2nd edn., 4 vols., I888), iii. 3II-I2.

102 Dowell, p. 3 I 2.

103 Petitions and Addresses to the House of Commons, Reasons Humbly Offered to the Consideration of the Knights, Citizens, and Burgesses . . . in Parliament Assembled, for a Duty on Raw Hides, etc. (I7II); Petitions and Addresses to the House of Commons, Reasons Humbly Offered by the Leather Dressers and Glovers, Shewing the Great Grievances that Will Be if a Duty be Laid on Sheep and Lamb-Skins, etc. (I7II); Petitions and Addresses to the House of Commons, Reasons Humbly to the Consideration of the Knights, Citizens and Burgesses in Parliament . . . against a Duty on Kid-Skins drest in Great Britain (I7I I).

104 Petitions and Address to the House of Commons, A proposal Humbly Offered to the Hon. House of Commons . . . Concerning the Management of the Duty on Leather (by John Goodwin) (I7IO?).

105 The Times, 20 Feb. I8I3, p. 3, col. b; 27 Feb. I8I3, p. 4, col. c; I3 May I8I3, p. 3, col. a. The overall duty informs us of a $13 \%$ decrease in the amount of leather produced in Britain in

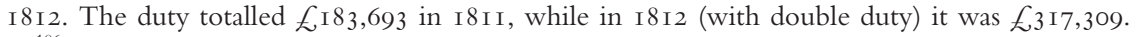

106 The Times, 20 May I8I3, p. 3, col. e; 2 I May I8I3, p. 3, col. a; I2 Apr. I8I6, p. 2, col. e.

107 The Times, I3 May i8 8 6, p. 3, col. d.

108 The Times, 28 Feb. I8I8, p. 2, col. b; I8 March I8I8, p. 3, col. d; 4 Apr. I8I8, p. 3, col. c; 20 June I822, p. I, col. d (petition from Ireland); I2 June I822, p. 2, col. b (petition from Scotland); I June I 822, p. 2, col. b (petition from Northumberland and Staffordshire); I May I822, p. I, col. e; 30 Apr. I822, p. I, col. c (petition from Northamptonshire).

109 McCulloch, p. 703 . 
The article has attempted to offer a comparative analysis of the French and the British leather markets in the eighteenth century. In France, the state assumed an organizational role in the creation of a national leather market. By contrast, in Britain the state simply regulated an existing market. These different political interventions influenced the development of leather production and the leather trades in the two countries. While France suffered from an endemic absence of leather, Britain was more effective in satisfying its increasing demand. The withdrawal of all duties on leather in Britain in I830 was a sign of the changes in the market and, at the same time, a confirmation of the success of the limited regulative action of the state. In France rising living standards and higher meat consumption allowed the increase of leather production and ensured that the manufacture of leather goods would be an important industry in Paris in the nineteenth century. 


\section{Please correct and return this set}

Please use the proof correction marks shown below for all alterations and corrections. If you wish to return your proof by fax you should ensure that all amendments are written clearly in dark ink and are made well within the page margins.

\begin{tabular}{|c|c|c|}
\hline Instruction to printer & Textual mark & Marginal mark \\
\hline Leave unchanged & ... under matter to remain & ( ) \\
\hline $\begin{array}{l}\text { Insert in text the matter } \\
\text { indicated in the margin }\end{array}$ & $h$ & $\begin{array}{l}\text { New matter followed by } \\
h \text { or } h \otimes\end{array}$ \\
\hline Delete & $\begin{array}{l}\text { I through single character, rule or underline } \\
\text { or }\end{array}$ & $\sigma$ or $\sigma / \otimes$ \\
\hline $\begin{array}{l}\text { Substitute character or } \\
\text { substitute part of one or } \\
\text { more word(s) }\end{array}$ & / through letter or & $\begin{array}{l}\text { new character / or } \\
\text { new characters / }\end{array}$ \\
\hline Change to italics & — under matter to be changed & $\leftarrow$ \\
\hline Change to capitals & $\equiv$ under matter to be changed & $\equiv$ \\
\hline Change to small capitals & $=$ under matter to be changed & $=$ \\
\hline Change to bold type & $\sim$ under matter to be changed & $\sim$ \\
\hline Change to bold italic & $\approx$ under matter to be changed & $\underline{s i n}$ \\
\hline Change to lower case & Encircle matter to be changed & $\not$ \\
\hline Change italic to upright type & (As above) & \\
\hline Change bold to non-bold type & (As above) & \\
\hline Insert 'superior' character & $\begin{array}{l}\text { I through character or } \\
K \text { where required }\end{array}$ & $\begin{array}{l}y^{\prime} \text { or } y \\
\text { under character } \\
\text { e.g. } y^{2} \text { or } y^{2}\end{array}$ \\
\hline Insert 'inferior' character & (As above) & $\begin{array}{l}\text { L } \\
\text { over character } \\
\text { e.g. } \hat{\imath}\end{array}$ \\
\hline Insert full stop & (As above) & $\odot$ \\
\hline Insert comma & (As above) & , \\
\hline Insert single quotation marks & (As above) & $\begin{array}{l}\dot{y} \text { or } \dot{X} \text { and/or } \\
\dot{y} \text { or } \dot{X}\end{array}$ \\
\hline Insert double quotation marks & (As above) & $\begin{array}{l}\dddot{y} \text { or } \ddot{x} \text { and/or } \\
\ddot{y} \text { or } \ddot{x}\end{array}$ \\
\hline Insert hyphen & (As above) & $1-1$ \\
\hline Start new paragraph & $\digamma$ & 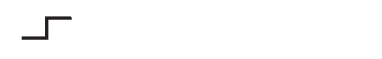 \\
\hline No new paragraph & $\infty$ & $\omega$ \\
\hline Transpose & $\sqcup$ & ᄃ \\
\hline Close up & linking $\bigcirc$ characters & \\
\hline $\begin{array}{l}\text { Insert or substitute space } \\
\text { between characters or words }\end{array}$ & $\begin{array}{l}\text { I through character or } \\
\Lambda \text { where required }\end{array}$ & \\
\hline $\begin{array}{l}\text { Reduce space between } \\
\text { characters or words }\end{array}$ & $\begin{array}{l}\text { between characters or } \\
\text { words affected }\end{array}$ & $\uparrow$ \\
\hline
\end{tabular}

